\title{
PLL 回路を用いた単相回路における簡易な有効・無効電流検出法
}

松本脩平* (山口大学) 田中俊彦, 平木英治（山口大学大学院）

大村泰（新居浜工業高等専門学校）山本真義（島根大学）

\section{1 、まえがき}

著者らは先に, 単相回路において相関と相互相関に着目 した有効・無効電流検出法を提案し，その有効性を明らか にした ${ }^{[1]}$ 。本稿では, PLL 回路を用いた単相回路における簡 易な有効・無効電流検出法を提案し, 計算機シミュレーシ ヨンにより，その有効性を確認する。

\section{PLL を用いた単相回路の有効・無効電流検出法}

図 1 に提案する単相回路の有効・無効電流検出法のブロ

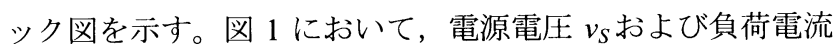
$i_{L}$ は次式で表されるものとする。

$$
\begin{aligned}
& v_{S}=\sqrt{2} V \sin \omega t \\
& i_{L}=\sqrt{2} I \sin (\omega t-\phi)
\end{aligned}
$$$$
\text { .............. }
$$

(1)式の $i_{L}$ に PLL 回路出力の $v_{P}=\sqrt{2} \sin \omega t$ を乗ずると,

$$
v_{P} \cdot i_{L}=I \cos \phi-I \cos \phi \cos 2 \omega t-I \sin \phi \sin \omega t
$$

となる。LPF により直流分を抽出し，再び $v_{p}$ を掛けること により, 次式を得る。

$$
i_{L p}=\sqrt{2} I \cos \phi \sin \omega t
$$

これは, 負荷電流 $i_{L}$ の有効電流分を示している。同様の方 法で, 無効電流分 $i_{L q}$ も検出できる。

\section{3. シミュレーション結果}

図 2 に, 単相アクティブフィルタ構成図を示す。負荷電 流 $i_{L}$ を検出し, 有効電流 $i_{L p}$ および無効電流 $i_{L_{q}}$ を演算する。 これらを， $i_{L}$ から減算することにより, 高調波補償指令值 $i_{h}$ を与える。アクティブフィルタの電流指令值 $i_{C}{ }$ は, この高 調波に直流キャパシタ電圧一定制御のための有効電流成分 $i_{D C}^{*}$ を加えたものとなる。

図 3,にアクティブフィルタ起動前後のシミュレーション 波形を示す。 $v_{S}$ は柱上変圧器の高圧側の電圧波形， $i_{S}$ は高圧 側の電流， $i_{R e c}$ はダイオード整流回路に流入する電流， $i_{C}$ は アクティブフィルタの出力する補償電流, $v_{D C}$ は直流キャパ シタ電圧である。アクティブフィルタ起動後は, 電源電流 $i_{S}$ は正弦波となっているが，無効電流 $i_{L q}$ を補償していない ため, 力率が 1.0 となっていない。

\section{4.まとめ}

本稿では, PLL 回路を用いた単相有効・無効電流検出法 を提案し，その有効性を計算機シミュレーションにより確 認した。
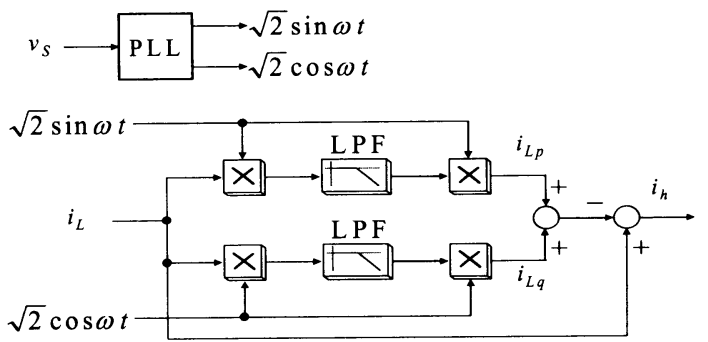

図 1. PLL を用いた有効・無効電流検出のブロック図 $105 \mathrm{~V}, 95.23 \mathrm{~A}$

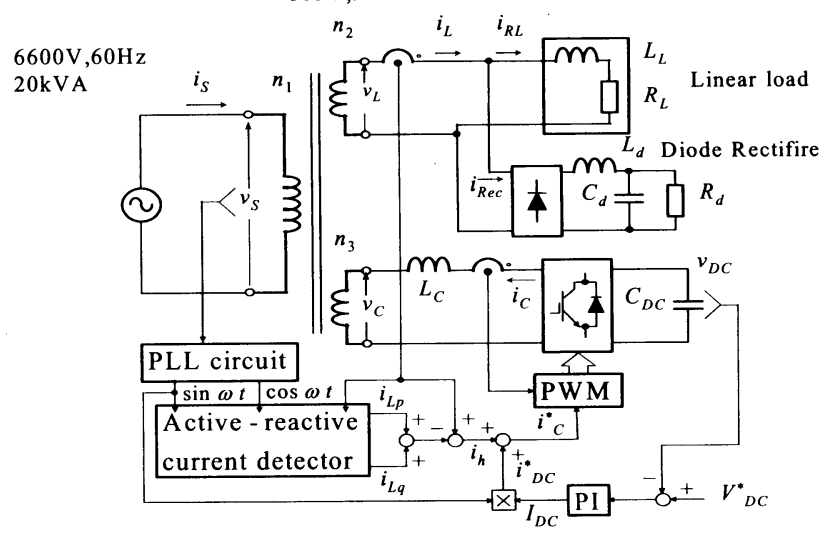

図 2. 単相アクティブフィルタ構成図

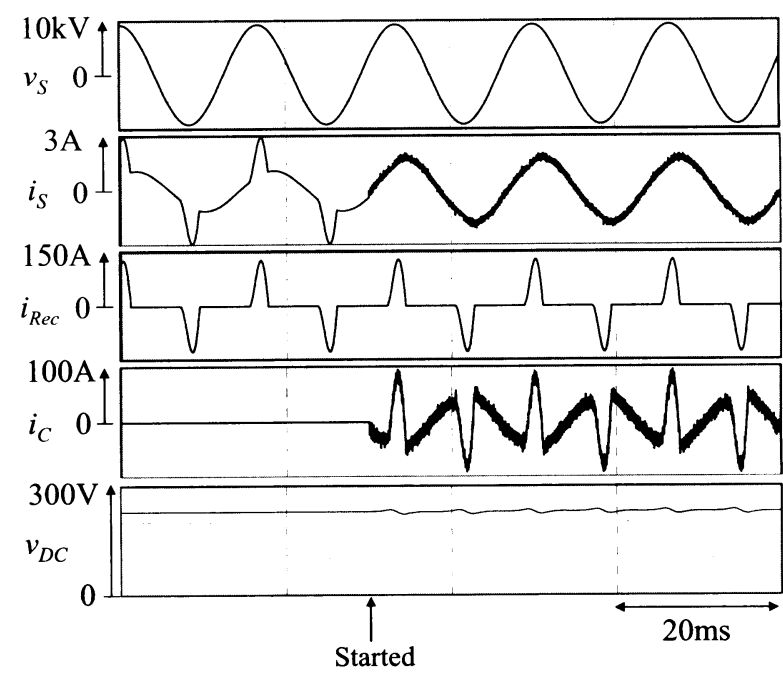

図 3. アクティブフィルタ起動時のシミュレーション波形 文 献

[1] T. Tanaka, K. Ueda, K. Sato, and S. Fukuma, "A Novel Detection Method of Active and Reactive Currents in Single Phase Circuits Using the Correlation and Cross-Correlation Coefficients and Its Applications", in Cof. Record of 39th IEEE-IAS Annual Meeting, 22p1, 2004 . 